\title{
Research Article \\ The Influence of English Ability and Educational Methods on the Military Vehicles Operationalization for Cadets in the Army and Military Academy at Cavalry Educational Center, Padalarang, Indonesia
}

\author{
Fauziyah Aulia Rishanti \\ Indonesia Defence University, Indonesia
}

\begin{abstract}
English skills are needed in the military field which always faces dynamic conditions. This research was intended to determine the relationship between English ability and educational methods used by military cadets at the Pusat Pendidikan Kavaleri on their ability to operate military vehicles. The method used is a quantitative method with population were all Army Secapa cadets and the Indonesian Army Military Academy who were currently studying at the Cavalry Education Center (Pusdik Kav) in Padalarang, West Java Province, Indonesia. Data collection technique used was observational technique, which was to examine directly by using a questionnaire and interview. The result of this research is that there is a significant relationship between the English Ability and the Educational method on military vehicles operationalization. In other words, if the English Ability and the Educational method is increased, the military vehicles operationalization for the Indonesian Army will be greater. In addition, the findings of this research are useful for military cadets and institution itself.
\end{abstract}

Keywords: English skills, Educational, Military, Vehicles.

This is an open access article under the CC-BY-NC license.

\section{INTRODUCTION}

The dynamic global security environment encourages countries to increase their military capabilities. One of the important things is related to the capability of military personnel in mastering English. The ability to speak English is needed by military personnel because it will be in direct contact with each assignment. Moreover, various security threats that are currently developing require the active participation of countries in efforts to maintain world peace through sending peacekeeping operations to various conflict areas, increasing military cooperation between countries, as well as with international organizations which of course will involve the role of military personnel. .

English is an introduction to technology transfer, as well as an international language in the field of science and technology. Part of the defense equipment owned by the Indonesian Army is the result of foreign production which is equipped with English implementation and operating instructions. For this reason, the personnel manning the Alutsista are required to understand well all the instructions and rules written in English, in order to be able to operate properly (Herman, 2016). English language material has been included in the educational curriculum at the Military Academy, in addition, there is also an Intensive English Course program which aims to develop the ability of officers, non-commissioned officers and enlisted personnel as well as civil servants of the Indonesian Army to have the knowledge and skills of Level I English ALC (American Language Courses). Meanwhile, the output task is expected to be able to carry out duties as a companion for foreign guests who come to the unit. With this course, personnel are able to translate a limited number of general texts/technical instructions for the TNI AD Alutsista equipment. Thus the implementation of the tasks 
of the Indonesian Army in the framework of international cooperation in the field of Defense can be achieved (Herman, 2016).

To optimize the implementation of tasks, especially related to defense equipment and how to operate the equipment, the leadership of the Pusdik provides opportunities for Indonesian Military Cadets to take English language education. Because by learning and understanding English at the same time, ensure the military ability to transfer knowledge and technology as well as information in a better, reliable and professional manner according to the leadership's policy to make the TNI become the world's number 1 army (Siagian, 2013).

The ability to speak English currently plays an important role where English as a means of global communication, English should be actively mastered both orally and in writing. "It can be said that English is not only a global communication medium, English is also an academic need whose mastery can be used as an added value for Air Force personnel," he said. In addition, in the future the Indonesian Air Force is also faced with modernizing the main defense equipment system with the implementation and operation procedures based on English.

For this reason, this course is the first step and provision for military cadets who will carry out assignments and education abroad as well as to improve the quality of human resources in order to oversee the defense equipment system.

The problem with many English instructors in the military is that they rely too much on the available textbooks. They can remotely evaluate their suitability based on personal experience, and are unwilling to carry out the necessary analysis of specialist texts which are difficult to verify their contents (Jodai, 2012).

\section{RESEARCH METHOD}

The research approach that will be carried out by the researcher is using a quantitative approach, where the quantitative approach is research in the form of numbers to test a hypothesis. Quantitative research is a research method based on the philosophy of positivism, used to examine certain populations or samples, data collection using research instruments, data analysis is quantitative or statistical, with the aim of testing established hypotheses (Sugiyono, 2013).

The type of research that will be used is associative research (relationship) with quantitative analysis methods (data in the form of numbers). Associative research is research that aims to determine the relationship between two or more variables. This research has the highest level when compared to descriptive and comparative research. With this research it will be possible to build a theory that can function to explain, predict and control a symptom (Sugiyono, 2007).

The population is a generalization area consisting of objects or subjects that have certain qualities and characteristics determined by the researcher to be studied and then draw conclusions. So the population is not only people, but also objects and other natural objects. The population is also not just the number that exists in the object or subject being studied, but includes all the characteristics or properties possessed by the subject or object (Sugiyono, 2007).

The population used in this study were all Army Secapa cadets and the Indonesian Army Military Academy who were currently studying at the Cavalry Education Center (Pusdik Kav) in Padalarang, West Java Province, Indonesia. 


\section{Sample}

The sample is part of the number and characteristics possessed by the population. If the population is large, and the researcher is not able to study everything in the population, for example due to limited funds, manpower and time, the researcher can use samples taken from that population. The sample selected based on Slovin's theory is.

where :

$$
n=\frac{N}{1+N \cdot e^{2}}
$$

$\mathrm{n}=$ sample size

$\mathrm{N}=$ population size

$\mathrm{e}=$ percent leeway in inaccuracy due to sampling errors that can still be tolerated or desired, for example $2 \%$ (Muhammad, 2013)

Based on data on the number of cadets from the Military Academy and Army Staff who are currently taking Branch Education at the Cavalry Pusdik, it shows that the total number of cadets is 59 in August-September 2021. So, with a population of 59 personnel, the sample size of this study uses the level of an error of $10 \%$ is:

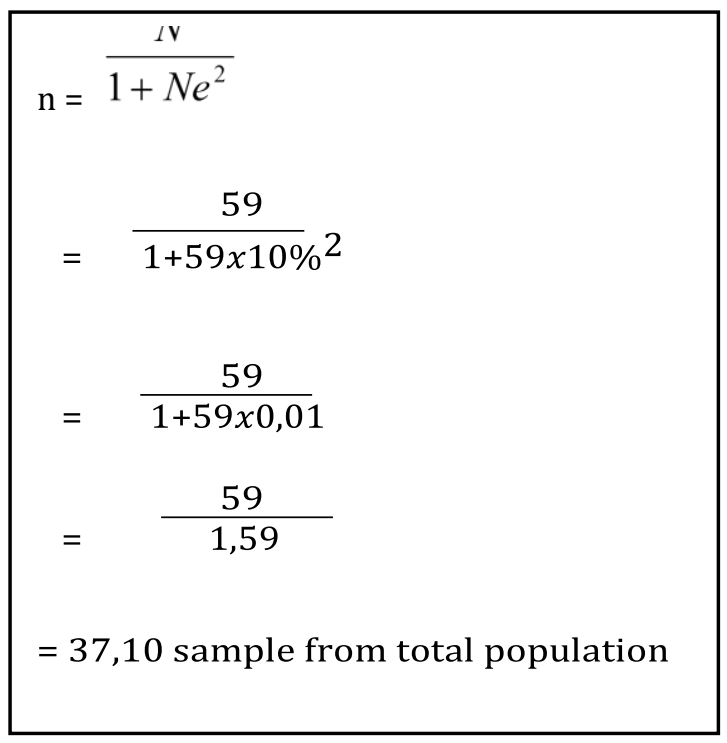

\section{Data Collection Technique}

The research data collection technique used was observational technique, which was to examine directly by using a questionnaire (questionnaire). Questionnaire is a data collection technique that is done by giving a set of questions or written statements to respondents to answer (Wiratna, 2015).

This questionnaire was given to cadets of the Military Academy and Army Staff who are currently undergoing branch education at the Cavalry Education Center in Padalarang, West Java. In addition to using questionnaires, another thing that is used in the observation technique is interviews. Interviews are used as a data collection technique if they want to find out the background of the problem that must be studied, and also if the researcher wants to know things from respondents who are more in-depth and the number of 
respondents is small (Sugiyono, 2017).

\section{Data Processing Techniques}

After the data is collected, then the data processing of the research results is carried out. Data processing is carried out through the following stages:

1. Editing

Editing is the process of checking or checking data that has been successfully collected from the field, because there is a possibility that the data that has been entered does not meet the requirements or is not needed. The purpose of editing is to correct errors and lack of data contained in the notes in the field. On that occasion, data errors can be corrected and data deficiencies are supplemented by repeating data collection or by inserting data (interpolation).

2. Coding

Codeting is the activity of giving a certain code to each data that is included in the same category. Code is a signal made in the form of numbers or letters to distinguish between data or the identity of the data to be analyzed.

3. Tabulation

Tabulation is the process of placing data into a tabular form that has been coded according to the needs of the analysis

\section{Data analysis technique}

In quantitative research, data analysis technique is a type of statistical test that will be used in research. There are various types of data analysis techniques. And what needs to be considered in choosing a data analysis technique, not the level of technical complexity, the data analysis technique in this study is valid, meaning that the instrument can be used to measure what is to be measured. In other words, the instrument is able to obtain the right data from the variables studied. In this study, the instrument used to measure what is to be measured in other words, the instrument is able to obtain precise data from the variables studied. In this study, the instrument used to collect data must be able to measure what it wants to measure.

\section{FINDING AND DISCUSSION}

\section{Validity test}

Validity test is carried out to test the level of accuracy (validity) of the size of an instrument against the concept under study. In conducting the validity test, testing was carried out for each independent instrument. The validity test was conducted on 32 statements addressed to 37 respondents with a degree of confidence $(\alpha)$ of $5 \%$.

There are two steps that can be used in the validity test, namely by using a comparison of the $r$ value or the value of Sig. If you want to use a comparison of the value of $r$, it is necessary to first know the value of the $r$ table that will be used. With a total of 37 respondents, it can be determined that the value of $r$ table in this validity test is $0.2096(\alpha ; n-2)$. The next step is to perform statistical tests using SPSS to find the calculated $r$ value for each research instrument. If $r$ count $>r$ table, then the item under study can be declared valid.

The results of data processing can also be used to test the validity without using $r$ arithmetic and $r$ tables, namely by paying attention to the value of Sig. each instrument. An instrument will be declared valid if the value of Sig. owned is less than $0.05(\leq 0.05)$. Through the Pearson correlation test, the results of the validity test for all variables in this study were obtained: 
The Influence of English Ability and Educational Methods on the Military Vehicles Operationalization for Cadets in the Army and Military Academy at Cavalry Educational Center, Padalarang, Indonesia

\section{a. Variable English Ability ( $\left.\mathrm{X}_{1}\right)$}

The validity test was conducted to test the validity of the instrument from the ability to speak English. The following are the results of the validity test of the questionnaire items related to English language skills:

Table 1 Test the Validity of Research Instruments Variable English Ability (X1)

\begin{tabular}{|c|c|c|c|c|}
\hline No & Statements & $\mathbf{r}_{\text {count }}$ & $\mathbf{r}_{\text {Table }}$ & Mark \\
\hline 1 & Statement 1 & 0,2096 & 0,496 & Valid \\
\hline 2 & Statement 2 & 0,2096 & 0,413 & Valid \\
\hline 3 & Statement 3 & 0,2096 & 0,309 & Valid \\
\hline 4 & Statement 4 & 0,2096 & 0,519 & Valid \\
\hline 5 & Statement 5 & 0,2096 & 0,195 & Invalid \\
\hline 6 & Statement 6 & 0,2096 & $-0,019$ & Invalid \\
\hline 7 & Statement 7 & 0,2096 & 0,478 & Valid \\
\hline 8 & Statement 8 & 0,2096 & 0,707 & Valid \\
\hline 9 & Statement 9 & 0,2096 & 0,727 & Valid \\
\hline 10 & Statement 10 & 0,2096 & 0,748 & Valid \\
\hline 11 & Statement 11 & 0,2096 & 0,654 & Valid \\
\hline 12 & Statement 12 & 0,2096 & 0,662 & Valid \\
\hline 13 & Statement 13 & 0,2096 & 0,689 & Valid \\
\hline 14 & Statement 14 & 0,2096 & 0,650 & Valid \\
\hline 15 & Statement 15 & 0,2096 & 0,592 & Valid \\
\hline 16 & Statement 16 & 0,2096 & 0,409 & Valid \\
\hline
\end{tabular}

Source: SPSS Processing Research Data, 2021

Based on Table 1 above, it can be concluded that almost all questionnaire items that represent $\mathrm{X} 1$ are valid. In testing the validity using the value of $r$ table and $r$ count, a statement can be said to be valid if the value of $r$ count $>r$ table. Referring to the middle of Table 1 above, it was found that two items of X1 instrument were declared invalid because they had an $r$ arithmetic value that was smaller than $r$ table. The two statements are X1.5 and X1.6. Therefore, the two items were eliminated from the statistical test process so as to produce a new $\mathrm{X} 1$ validity test. Thus, Table 2 displays the results of the new $\mathrm{X} 1$ validity test.

Table 2. X Validity Test (After Elimination)

\begin{tabular}{|c|c|c|c|c|c|}
\hline No & Statements & r count & r Table & Sig. & Mark \\
\hline 1 & Statement 1 & 0,2096 & 0,516 & 0,000 & Valid \\
\hline 2 & Statement 2 & 0,2096 & 0,390 & 0,000 & Valid \\
\hline
\end{tabular}


The Influence of English Ability and Educational Methods on the Military Vehicles Operationalization for Cadets in the Army and Military Academy at Cavalry Educational Center, Padalarang, Indonesia Fauziyah Aulia Rishanti

\begin{tabular}{|c|c|c|c|c|c|}
\hline 3 & Statement 3 & 0,2096 & 0,286 & 0,007 & Valid \\
\hline 4 & Statement 4 & 0,2096 & 0,516 & 0,000 & Valid \\
\hline 5 & Statement 5 & 0,2096 & 0,519 & 0,000 & Valid \\
\hline 6 & Statement 6 & 0,2096 & 0,713 & 0,000 & Valid \\
\hline 7 & Statement 7 & 0,2096 & 0,722 & 0,000 & Valid \\
\hline 8 & Statement 8 & 0,2096 & 0,801 & 0,000 & Valid \\
\hline 9 & Statement 9 & 0,2096 & 0,669 & 0,000 & Valid \\
\hline 10 & Statement 10 & 0,2096 & 0,665 & 0,000 & Valid \\
\hline 11 & Statement 11 & 0,2096 & 0,726 & 0,000 & Valid \\
\hline 12 & Statement 12 & 0,2096 & 0,657 & 0,000 & Valid \\
\hline 13 & Statement 13 & 0,2096 & 0,643 & 0,000 & Valid \\
\hline 14 & Statement 14 & 0,2096 & 0,458 & 0,000 & Valid \\
\hline
\end{tabular}

Source: SPSS Processing Research Data, 2021

Based on Table 2 above, it can be seen that all X1 instruments have passed the validation test. Thus, all the instruments for English Ability (X1) which have been declared valid are 14 points.

\section{b. Educational Method (X2)}

In addition to X1, this study also operationalizes X2 which is a dimension of Crew Competence. Like $\mathrm{X} 1, \mathrm{X} 2$ will also be tested for its validity value using Pearson Correlation. Table 4.3 below displays the results of the analysis of the validity of $\mathrm{X} 2$.

Table 3. Research Instrument Validity Test of Researcher Competency Variables (X2)

\begin{tabular}{|c|c|c|c|c|c|}
\hline No & Statements & $\mathbf{r}_{\text {count }}$ & $\mathbf{r}_{\text {Table }}$ & Sig. & Mark \\
\hline 1 & Statement 17 & 0,2096 & 0,506 & 0,000 & Valid \\
\hline 2 & Statement 18 & 0,2096 & 0,561 & 0,000 & Valid \\
\hline 3 & Statement 19 & 0,2096 & 0,733 & 0,000 & Valid \\
\hline 4 & Statement 20 & 0,2096 & 0,615 & 0,000 & Valid \\
\hline 5 & Statement 21 & 0,2096 & 0,708 & 0,000 & Valid \\
\hline 6 & Statement 22 & 0,2096 & 0,711 & 0,000 & Valid \\
\hline 7 & Statement 23 & 0,2096 & 0,553 & 0,000 & Valid \\
\hline 8 & Statement 24 & 0,2096 & 0,649 & 0,000 & Valid \\
\hline
\end{tabular}

Source: SPSS Processing Research Results Data, 2021

Based on Table 3 above, it can be concluded that all instruments from X2 or Manning Competence can be declared to have passed the validity test. This is because the overall value of Sig. obtained is less than 0.05 , or the entire value of $r$ count $>$ from the value of $r$ table. Thus, all of the independent variable questionnaire items used in this study were valid. 
The Influence of English Ability and Educational Methods on the Military Vehicles Operationalization for Cadets in the Army and Military Academy at Cavalry Educational Center, Padalarang, Indonesia Fauziyah Aulia Rishanti

\section{c. Military Equipment Operationalization (Y)}

In addition to the independent variables, this study also tested the validity of the questionnaire statement items related to the distribution of the TNI Army logistics which was the dependent variable. Table 4.4 below shows the results of the analysis of the validity of the Y variable.

Table 4. Research Instrument Validity Test of Military Equipment Operationalization (Y)

\begin{tabular}{|c|c|c|c|c|c|}
\hline No & Statement & $\mathbf{r}_{\text {count }}$ & $\mathbf{r}_{\text {Table }}$ & Sig. & Mark \\
\hline 1 & Statement 25 & 0,2096 & 0,472 & 0,000 & Valid \\
\hline 2 & Statement 26 & 0,2096 & 0,481 & 0,000 & Valid \\
\hline 3 & Statement 27 & 0,2096 & 0,670 & 0,000 & Valid \\
\hline 4 & Statement 28 & 0,2096 & 0,533 & 0,000 & Valid \\
\hline 5 & Statement 29 & 0,2096 & 0,604 & 0,000 & Valid \\
\hline 6 & Statement 30 & 0,2096 & 0,584 & 0,000 & Valid \\
\hline 7 & Statement 31 & 0,2096 & 0,597 & 0,000 & Valid \\
\hline 8 & Statement 32 & 0,2096 & 0,604 & 0,000 & Valid \\
\hline
\end{tabular}

Source: SPSS Processing Research Results Data, 2021

Based on Table 4 above, it can be concluded that all instruments from $Y$ or the logistics distribution of the Indonesian Army can be declared to have passed the validity test. This can be seen from the overall value of the calculated $r$ which is greater than the $r$ table. In addition, the overall value of Sig. obtained is less than 0.05 . Thus, all questionnaire items used in this study are valid.

\section{Reliability Test}

After testing the validity, the next test is the reliability test. Reliability test is conducted to test the reliability of an instrument that does not contain bias. This test can refer to the Cronbach value. If the Cronbach value obtained is more than 0.7 , then the instrument can be said to have passed the reliability test.

By using SPSS software, each independent variable in this study was tested for reliability. Table 5 below shows the results of reliability testing for X1 and X2.

Table 5 Reliability Test

\section{Reliability Statistics}

\begin{tabular}{|c|r|r|}
\hline Variabel & Cronbach's Alpha & N of Items \\
\hline$X_{1}$ & .856 & 14 \\
\hline$X_{2}$ & .780 & 8 \\
\hline$Y$ & .720 & 7 \\
\hline
\end{tabular}

Source: SPSS Processing Research Results Data, 2021

By paying attention to the value of Cronbach's Alpha, it can be concluded that $\mathrm{X} 1, \mathrm{X} 2$, and $\mathrm{Y}$ have values above 0.7. The value of Cronbach's Alpha X1 of 0.817 and X2 of 0.783 indicates that both have passed the reliability test. Thus, all instrument variables are reliable or reliable in this study. 


\section{Normality test}

The next test is the normality test. The normality test is carried out to measure whether the data we have is normally distributed so that it can be used in parametric statistics. This study uses the Kolmogorov Smirnov test with the assumption of normality when the value of Sig. above $0.05(>0.05)$. The following table 6 below shows the results of the normality test in this study.

Table 6 Normality Test

One-Sample Kolmogorov-Smirnov Test

\begin{tabular}{|ll|r|}
\hline & & $\begin{array}{c}\text { Unstandardized } \\
\text { Residual }\end{array}$ \\
\hline N & Mean & 88 \\
Normal Parameters & \\
& Std. Deviation & .0000000 \\
Most Extreme Differences & Absolute & 1.96725419 \\
& Positive & .103 \\
& Negative & .037 \\
Kolmogorov-Smirnov Z & &. .103 \\
Asymp. Sig. (2-tailed) & & .968 \\
\hline a. Test distribution is Normal. & .306 \\
\hline
\end{tabular}

Source: SPSS Processing Research Results Data, 2021

Based on the Asymp value. Sig. (2-tailed) in Table 4.10 above, the Unstandardized Residual value obtained is 0.306 . This indicates that the data in this study have passed the normality test due to the Asymp Sig. value is above 0.05 . Thus, all data in this study were normally distributed.

\section{Multicollinearity Test}

Multicollinearity test was conducted to see causality between independent variables or the fact that the explanatory variables were jointly influenced by a third variable that was outside the model. By using the Coefficients Table from statistical analysis, the results are shown in Table 7 below:

Table 7 Multikolinearitas Coefficients Testa

\begin{tabular}{|c|c|c|c|c|c|c|c|c|}
\hline & \multirow[b]{2}{*}{ Model } & \multicolumn{2}{|c|}{$\begin{array}{l}\text { Unstandardized } \\
\text { Coefficients }\end{array}$} & \multirow{2}{*}{$\begin{array}{c}\text { Standardized } \\
\text { Coefficients }\end{array}$} & \multirow[b]{2}{*}{$\mathrm{t}$} & \multirow[b]{2}{*}{ Sig. } & \multicolumn{2}{|c|}{$\begin{array}{c}\text { Collinearity } \\
\text { Statistics }\end{array}$} \\
\hline & & B & Std. Error & & & & Tolerance & VIF \\
\hline \multirow[t]{3}{*}{1} & (Constant) & 9.872 & 2.188 & & 4.512 & .000 & & \\
\hline & TOTAL_X1 & .108 & .039 & .264 & 2.729 & .008 & .626 & 1.597 \\
\hline & TOTAL_X2 & .418 & .078 & .517 & 5.348 & .000 & .626 & 1.597 \\
\hline
\end{tabular}

a. Dependent Variable: TOTAL_Y

Source: SPSS Processing Research Results Data, 2021

In table 7. above, the results show that the VIF and Tolerance values of each independent variable have passed the assumptions. Tolerance values for X1 and X2 are 0.626 , respectively. While the VIF values of X1 and $\mathrm{X} 2$ are 1.597, respectively. Based on the assumption, a data avoids multicollinearity if it has a VIF value $<10$ 
The Influence of English Ability and Educational Methods on the Military Vehicles Operationalization for Cadets in the Army and Military Academy at Cavalry Educational Center, Padalarang, Indonesia Fauziyah Aulia Rishanti

and a Tolerance $>0.1$. This indicates that the instrument data $\mathrm{X} 1$ and $\mathrm{X} 2$ have avoided multicollinearity because the VIF value is less than 10 and the tolerance is above 0.1 . Therefore, it can be concluded that all data in this study are free from multicollinearity.

\section{Heteroscedasticity Test}

Heteroscedasticity testing aims to determine whether in a regression model there is an inequality of variance from the residual of one observer to another observer. In this test, the assumption that is used as a reference is if the value of Sig. > 5\%. Table 8 below shows the results of the heteroscedasticity test in this study.

Table 8 Heteroscedasticity Test

Coefficients $^{\mathbf{a}}$

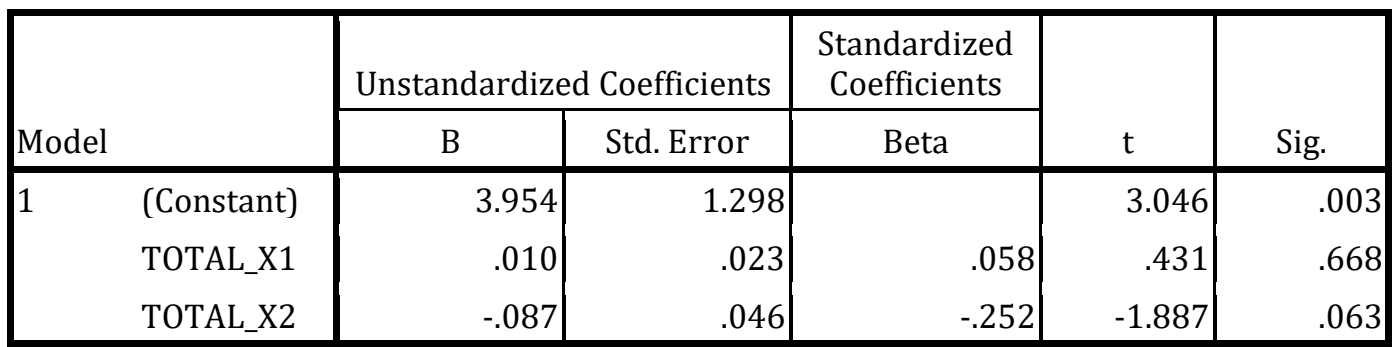

a. Dependent Variable: Abs_res

Source: SPSS Processing Research Results Data, 2021

Based on Table 8 above, the value of Sig. for each independent variable is 0.668 and 0.063 . Assuming that a data avoids heteroscedasticity if the value of Sig. is above 5\%, it can be concluded that the data in this study is free from heteroscedasticity. Henceforth, all statement items in this questionnaire can be used as research measuring tools.

\section{Data processing}

Correlation of English Ability (X1), Educational method (X2), and Military vehicles operationalization (Y). Based on the results of processing on SPSS, the following are the results of the Correlation Test between Variables

Table 9. Correlation of English Ability Variables (X1), Educational Method (X2), and Military Vehicles Operationalization (Y)

\begin{tabular}{|ll|r|r|r|}
\hline & \multicolumn{1}{c|}{ Correlations } & \\
\hline TOTAL_X1 & TOTAL_X1 & TOTAL_Y & TOTAL_X2 \\
& Pearson Correlation & 1 & $.580^{* *}$ & $.611^{* *}$ \\
& Sig. (2-tailed) & .000 & .000 \\
& $\mathrm{~N}$ & 88 & 88 & 88 \\
\hline TOTAL_Y & Pearson Correlation & $.580^{* *}$ & 1 & $.678^{* *}$ \\
& Sig. (2-tailed) & .000 & .000 \\
& $\mathrm{~N}$ & 88 & 88 & 88 \\
\hline TOTAL_X2 & Pearson Correlation & $.611^{*+}$ & $.678^{* *}$ & 1 \\
& Sig. (2-tailed) & .000 & .000 & 88 \\
& $\mathrm{~N}$ & 88 & 88 \\
\hline
\end{tabular}

**. Correlation is significant at the 0.01 level (2-tailed).

Source: SPSS Processing Results, 2021 
In Table 9 above, the test results show that there is a strong and positive influence between English ability (X1) on the Army's Logistics Distribution, which is 0.580. By using the coefficient of determination, the result is $33.64 \%$ (KD = r2 $\times 100 \%$ ) which is the English ability (X1) in influencing the military vehicles operationalization $(\mathrm{Y})$. While the remaining $66.36 \%$ is influenced by other factors outside the model.

In addition, Table 9 above also shows that there is a strong and positive influence between Crew Competence (X2) on the Army's Logistics Distribution, which is 0.678. By using the coefficient of determination, the result is $45.97 \%$ (KD $=\mathrm{r} 2 \times 100 \%$ ). This shows that the educational method on English (X2) can affect the military vehicles operationalization $(\mathrm{Y})$ by $45.97 \%$, while the remaining $54.03 \%$ is influenced by other factors outside the model.

\section{Data analysis \\ Multiple Correlation Analysis}

Multiple correlation analysis was carried out to find out how much influence the independent variable had with the dependent variable in this study. In this test, a relationship can be declared significant if the value of Sig. F Change $<0.05$. Meanwhile, to determine the level of relationship, the following guidelines for the degree of relationship are used in this study:

a) 0.199 indicates a very low level of relationship

b) $0.20-0.399$ indicates a low level of relationship

c) $0.40-0.599$ indicates a moderate level of relationship

d) $0.60-0.799$ indicates the level of a strong relationship

e) $0.80-1.00$ indicates the level of the relationship is very strong

Based on the results of statistical tests, the results obtained as Table 10 show as follows:

Table 10. Multiple Correlation Coefficient

Model Summaryb

\begin{tabular}{|c|c|c|c|c|c|c|c|c|c|}
\hline \multirow[b]{2}{*}{$\begin{array}{l}\text { Mode } \\
1\end{array}$} & \multirow[b]{2}{*}{$\mathrm{R}$} & \multirow[b]{2}{*}{ R Square } & \multirow[b]{2}{*}{$\begin{array}{c}\text { Adjusted R } \\
\text { Square }\end{array}$} & \multirow[b]{2}{*}{$\begin{array}{l}\text { Std. Error of } \\
\text { the Estimate }\end{array}$} & \multicolumn{5}{|c|}{ Change Statistics } \\
\hline & & & & & $\begin{array}{l}\text { R Square } \\
\text { Change }\end{array}$ & F Change & df1 & df2 & Sig. F Change \\
\hline 1 & $.709^{a}$ & .503 & -491 & 1.990 & .503 & 43.030 & 2 & 85 & .000 \\
\hline
\end{tabular}

a. Predictors: (Constant), TOTAL_X1, TOTAL_X2

b. Dependent Variable: TOTAL_Y

Source: SPSS Processing Results, 2021

Based on Table 4.14 above, the value of Sig. The F Change $<0.05$ and the $\mathrm{R}$ value indicating the magnitude of the influence of the English ability variable (X1) and Educational method (X2) on the military vehicles operationalization $(\mathrm{Y})$ of 0.709 . This indicates that there is a strong and significant relationship between the variables. The multiple correlations that occur simultaneously between the variables of this study are $50.26 \%$ (R2 x 100\%) the English ability variable (X1) and Educational method (X2)) have a significant and 
The Influence of English Ability and Educational Methods on the Military Vehicles Operationalization for Cadets in the Army and Military Academy at Cavalry Educational Center, Padalarang, Indonesia Fauziyah Aulia Rishanti

positive influence on the military vehicles operationalization ( $Y$ ), while the remaining $49.74 \%$ is influenced by other variables not included in this study.

\section{Multiple Linear Regression Analysis}

Multiple regression analysis is used to determine the degree or strength of the relationship between two or more variables, and to determine the simultaneous contribution of the independent variable to the dependent variable. Based on the results of statistical analysis, the results obtained as Table 11 are presented as follows:

Table 11 English Ability Variables (X1), Educational Method (X2), and Military Vehicles Operationalization (Y)

\section{Coefficients $^{\mathbf{a}}$}

\begin{tabular}{|c|c|c|c|c|c|c|}
\hline \multirow{2}{*}{\multicolumn{2}{|c|}{ Model }} & \multicolumn{2}{|c|}{$\begin{array}{c}\text { Unstandardized } \\
\text { Coefficients }\end{array}$} & \multirow{2}{*}{$\begin{array}{c}\begin{array}{c}\text { Standardized } \\
\text { Coefficients }\end{array} \\
\text { Beta }\end{array}$} & \multirow[b]{2}{*}{$\mathrm{t}$} & \multirow[b]{2}{*}{ Sig. } \\
\hline & & B & Std. Error & & & \\
\hline \multirow[t]{3}{*}{1} & (Constant) & 9.872 & 2.188 & & 4.512 & .000 \\
\hline & TOTAL_X2 & .418 & .078 & .517 & 5.348 & .000 \\
\hline & TOTAL_X1 & .108 & .039 & .264 & 2.729 & .008 \\
\hline
\end{tabular}

a. Dependent Variable: TOTAL_Y

Source: SPSS Processing Results, 2021

Based on Table 4.15 above, the Constant value obtained is 9.872, the Total_X1 value is 0.108 and the Total_X2 value is 0.418 . Thus, the regression equation compiled in this study is:

$$
Y=9,872+0,108 X_{1}+0,418 X_{2}+e
$$

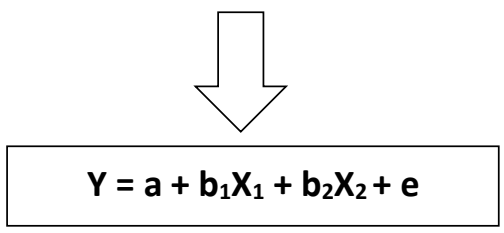

The interpretations for the regression equation are:

- $\mathrm{a}=9.872$; meaning that if $\mathrm{X} 1$ and $\mathrm{X} 2$ are 0 , then the change in $\mathrm{Y}$ is 9.872. In other words, if there is no English Ability and Educational Method, the Military Vehicles Operationalization will not be affected.

- $\quad \mathrm{b} 1=0.108$; meaning that if $\mathrm{X} 1$ increases by 1 , then the change in $\mathrm{Y}$ increases by 0.108 times. In this case, if the English Ability is increased, the Military Vehicles Operationalization will also increase.

- $\mathrm{b} 2=0.418$, meaning that if $\mathrm{X} 2$ increases by 1 , then the change in Y increases by 0.418 times. This means that if the competence of the crew is increased, the distribution of the TNI's logistics will also increase.

In this study, the data used are primary data obtained through a questionnaire and using a Likert scale as a measurement tool. Because the Likert scale value does not have a certain magnitude, the regression equation compiled above can only include the direction of influence on the dependent variable. 


\section{RESULTS}

After performing multiple regression test, it is possible to test the hypothesis for this research. Hypothesis testing was carried out on the correlation between variables in order to determine the significance of the effect of the independent variable on the dependent variable. The hypotheses proposed in this study are:

H0 There is no significant effect between English Ability (X1), Educational Method (X2) on Military Vehicles Operationalization (Y)

H1 There is a significant influence between the English Ability (X1) on the Military Vehicles Operationalization (Y)

H2 There is a significant influence of Educational Method (X2) on the Military Vehicles Operationalization (Y)

H3 There is a significant influence between the English Ability (X1), Educational Method (X2) on Military Vehicles Operationalization (Y)

\section{a. Significant Correlation of English Ability (X1), Educational Method (X2)}

This test aims to see the significance of the effect of the variable English Ability (X1) on the Military Vehicles Operationalization $(\mathrm{Y})$. Here is the analysis:

1) Hypothesis to be tested:

a) Hypothesis Statement:

Ho : There is no significant effect between the English Ability (X1) on the Military Vehicle Operationalization $(\mathrm{Y})$

Ha : There is a significant influence between the Modernization of the Army's Alutsista (X1) on the Army's Logistics Distribution (Y)

b) Hypotheses in the form of research statistical models

$$
\begin{aligned}
& \text { Ho }: \text { rx1. } y=0 \\
& \text { Ha }: r X 1, Y \neq 0
\end{aligned}
$$

2) Risk of error used $=5 \%(0.05)$

3) Decision criteria

If $=$ Sig. $<$, then Ho is rejected

If $=$ Sig. $>$, then Ho is accepted

In this study, the value of used is 0.05 . With a two-tailed (2-tailed) test, then the value of is divided by two, so that it becomes 0.025 . Based on the Correlation Table in Table 11 above, the value of Sig. The variable of English Ability (X1) on the military vehicles operationalization $(\mathrm{Y})$ is 0.000 .

4) The results of the research

Based on the results of the study, the value of Sig. <, i.e. $0.000<0.025$. Thus, Ho is rejected and Ha is accepted. So it can be concluded that there is a significant influence between the English Ability (X1) on the Military Vehicle Operationalization (Y). 


\section{b. The Significance of the Correlation of Educational Method (X2) on the Military Vehicles Operationalization (Y)}

This test aims to see the significance of the influence of the Educational Method (X2) on the Military Vehicles Operationalization (Y). Here is the analysis:

1) Hypothesis to be tested:

a) Hypothesis Statement:

Ho: There is no significant effect between Educational Method (X2) on Military Vehicles Operationalization (Y)

Ha: There is a significant influence between Educational Method (X2) on Military Vehicles Operationalization $(\mathrm{Y})$

b) Hypotheses in the form of research statistical models

Ho: $r \times 1 . y=0$

Ha: $r$ X1, Y 0

2) The risk of error used $=5 \%(0.05)$

3) Decision criteria

If $=$ Sig. $<$, then Ho is rejected

If $=$ Sig. $>$, then Ho is accepted

In this study, the value of used is 0.05 . With a two-tailed (2-tailed) test, then the value of is divided by two, so that it becomes 0.025. Based on the Correlation Table in Table 4.9 above, the value of Sig. the variable of Educational Method (X2) on Military Vehicles Operationalization (Y) is 0.000.

4) The results of the research

Based on the results of the study, the value of Sig. $<$, i.e. $0.000<0.025$. Thus, Ho is rejected and Ha is accepted. So it can be concluded that there is a significant influence between the Educational Method (X2) on Military Vehicles Operationalization (Y).

\section{c. Significance of Correlation Effect of English ability (X1), Educational method (X2) on the military vehicle operationalization $(\mathrm{Y})$.}

1) This test aims to see the significance of the influence between variables, namely English Ability (X1), Educational Method (X2), and Military Vehicles Operationalization (Y). Here is the analysis:

a) 1) Hypothesis to be tested:

a) Hypothesis Statement:

b) Ho : There is no significant effect between English Ability (X1), Educational Method (X2), and Military Vehicles Operationalization (Y)

c) Ha : There is a significant influence English Ability (X1), Educational Method (X2), and Military Vehicles Operationalization (Y)

d) Hypotheses in the form of research statistical models

Ho : $r x 1 . y=0$

Ha : $r$ X1,Y 0

2) The risk of error used $=5 \%(0.05)$ 


\section{3) Decision criteria}

$$
\begin{aligned}
& \text { If }=\text { Sig. }<, \text { then Ho is rejected } \\
& \text { If }=\text { Sig. }>, \text { then Ho is accepted }
\end{aligned}
$$

In this study, the value of used is 0.05 . With a two-tailed (2-tailed) test, then the value of is divided by two, so that it becomes 0.025 . Based on the Correlation Table in Table 4.9 above, the value of Sig. obtained are as follows:

a) Value of Sig. $\mathrm{X} 1-\mathrm{Y}<=0.000<0.025$

b) Value of Sig. X2-Y $<=0.000<0.025$

c) Value of Sig. X1-X2 $<=0.000<0.025$

4) The results of the research

Based on the results of the study, the value of Sig. $<$, for the overall relationship between variables is $0.000<0.025$. Thus, Ho is rejected and Ha is accepted. So it can be concluded that there is a significant influence between the English Ability (X1), Educational Method (X2), and Military Vehicles Operationalization (Y) .

\section{Regression Model Hypothesis}

Hypothesis testing on the multiple regression model in this study aims to test the significance simultaneously ( $\mathrm{F}$ test), or partially ( $\mathrm{T}$ test). The purpose of the test is to determine the influence of English Ability (X1), Educational Method (X2), and Military Vehicles Operationalization (Y) separately. Meanwhile, the simultaneous test ( $\mathrm{F}$ test) was conducted to determine the effect of the variable English Ability (X1), Educational Method (X2), and Military Vehicles Operationalization (Y) simultaneously.

\section{a. Partial Significance Test (t Test)}

This test was conducted to test the magnitude of the influence of the independent variable on the dependent variable separately. In this test, a comparison is made between the value of alpha $(\alpha)$ at a significance level of 5\% (0.005) against the value of $t$ Sig. on the basis of decision making as follows:

1) If the value of Sig. $<0.05$, or $t$ arithmetic $>t$ table, then there is an effect of variable $X$ on variable $Y$

2) If the value of Sig. $>0.05$, or $t$ arithmetic $<t$ table, there is no effect of variable $X$ on variable $Y$

As for determining the value of $t$ table, used a formula that is processed in the Microsoft Excel program. as follows :

\section{$\mathrm{t}$ table $=\operatorname{TINV}(\alpha ; n-k)$}

By using this formula, the $t$ table value for this research is 1.987. Next, a comparison is made between the $t$ table and the calculated $t$ obtained based on the information in Table 12 below: 
Table 12. T-Test Results (Partial)

Coefficients $^{\mathrm{a}}$

\begin{tabular}{|c|c|c|c|c|c|c|}
\hline \multirow{2}{*}{\multicolumn{2}{|c|}{ Model }} & \multicolumn{2}{|c|}{ Unstandardized Coefficients } & \multirow{2}{*}{$\begin{array}{c}\text { Standardized } \\
\text { Coefficients }\end{array}$} & \multirow[b]{2}{*}{$\mathrm{t}$} & \multirow[b]{2}{*}{ Sig. } \\
\hline & & B & Std. Error & & & \\
\hline \multirow[t]{3}{*}{1} & (Constant) & 9.872 & 2.188 & & 4.512 & .000 \\
\hline & TOTAL_X1 & .108 & .039 & .264 & 2.729 & .008 \\
\hline & TOTAL_X2 & .418 & .078 & .517 & 5.348 & .000 \\
\hline
\end{tabular}

a. Dependent Variable: TOTAL_Y

Source: SPSS Data Processing Results, 2021

Based on the results of the partial test ( $\mathrm{t}$ test) above, the following is the relationship between the independent variables (X1 and X2) and the dependent variable (Y).

1) It is known that the value of Sig. for the effect of $\mathrm{X} 1$ on $\mathrm{Y}$ is equal to $0.008<0.05$. It was also found that $t$ count $>t$ table, which is $2,729>1,987$. Thus, $H 1$ is accepted. This means that there is an influence of English Ability (X1) on the Military Vehicles Operationalization (Y).

2) It is known that the value of Sig. for the effect of $X 2$ on $Y$ is equal to $0.000<0.05$. It was also found that $t$ arithmetic $>t$ table, namely $5.348>1.987$. Thus, $\mathrm{H} 2$ is accepted. This means that there is an influence of Educational Method (X2) on the Military Vehicles Operationalization (Y).

\section{Simultaneous Significance Test (F Test)}

This test was conducted to determine the effect of the variables of the English literacy toward Indonesian Military Cadets, the Educational Method on the Military Vehicles Operationalization simultaneously. The following are the results of the F test analysis in this study:

Table 13 F Test (Simultaneous)

\begin{tabular}{|ll|r|r|r|c|c|}
\hline \multicolumn{1}{|c|}{ ANOVA $^{\mathbf{b}}$} \\
\hline 1 & Sum of Squares & \multicolumn{1}{c|}{ df } & Mean Square & F & \multicolumn{1}{c|}{ Sig. } \\
\hline & Regression & 340.893 & 2 & 170.447 & 43.030 & $.000^{\mathrm{a}}$ \\
& Residual & 336.698 & 85 & 3.961 & & \\
& Total & 677.591 & 87 & & & \\
\hline
\end{tabular}

a. Predictors: (Constant), TOTAL_X1, TOTAL_X2

b. Dependent Variable: TOTAL_Y

Source: SPSS Data Processing Results, 2021

The basis for decision making used in the $\mathrm{F}$ Test are:

1) If the value of Sig. $<0.05$, or $f$ arithmetic $>f$ table, then there is an effect of variable $X$ on variable $Y$ 
2) If the value of Sig. $>0.05$, or $f$ count $<\mathrm{f}$ table, there is no effect of variable $X$ on variable $Y$

As for determining the value of $t$ table, used a formula that is processed in the Microsoft Excel program. as follows :

\section{f table $=$ FINV $(\alpha ; k ; n-k)$}

By using this formula, the $t$ table value for this research is 3.1025. Based on Table 4.13 above, it is known that the value of Sig. is 0.000 which means $<0.05$. While the calculated $\mathrm{f}$ obtained is 43,030 . This indicates that X1 and X2 simultaneously have an effect on Y. In other words, the English Ability of troops and the Educational Method have an effect on the Military Vehicles Operationalization.

\section{CONCLUSIONS}

This study aims to determine and analyze the effect of the addition of English Ability on the Military Vehicles Operationalization of the Indonesian Army, to determine and analyze the effect of the competence of Military Cadets on the Vehicles Operationalization shift of the Indonesian Army, and to determine and analyze the addition of English Ability and the Educational Method simultaneously affect the military vehicles shift of Indonesian Army.

The discussion above in this study has discussed the influence of the research variables of English Ability (Speak, Pronounce, Reading and Adaptation), Educational Method on the Military Vehicles Operationalization for the Indonesian Army separately or simultaneously.

The results of the correlation test in this study indicate that changes in each independent variable will affect the results of the study or the dependent variable. In other words, if the English Ability and the Educational method is increased, the military vehicles operationalization for the Indonesian Army will be greater.

In the results of the multiple correlation test, it was found that the magnitude of the influence of the variable English ability and the educational method on the military vehicle operationalization, there is a strong and significant relationship between the variables. The correlation that occurs simultaneously is $50.26 \%$

For the results of the statistical test of the coefficient of determination, the result is that the coefficient of determination for the English Ability is $33.64 \%$ and educational method is $45.97 \%$. With this, the average contribution of the two independent variables to the military vehicles operationalization is $39.81 \%$. While the remaining $60.19 \%$ is influenced by other factors outside this research model.

Based on the results of the multiple regression test in this study, the results of the regression equation are as follows: $\mathrm{Y}=9.872+0.108 \mathrm{X} 1+0.418 \mathrm{X} 2$. The regression equation can explain the changes that can occur to the $\mathrm{Y}$ variable if there is an increase in the $\mathrm{X} 1$ and $\mathrm{X} 2$ variables. If there is an increase in one value in the $\mathrm{X} 1$ variable, there will be an increase of 0.108 times. Likewise with an increase in one value of the X2 variable, it will increase the increase in the value of $Y$ by 0.418 times.

The results of partial hypothesis testing using the t-test obtained the results that there was a significant effect, both between the English ability and the educational method on the military vehicles operationalization separately. Meanwhile, in the simultaneous test, the results show that the English ability and the educational method simultaneously significantly affects the military vehicles operationalization.

|71

ISSN 2776-4524 (Online) | 2776-4184 (Print) 
The Influence of English Ability and Educational Methods on the Military Vehicles Operationalization for Cadets in the Army and Military Academy at Cavalry Educational Center, Padalarang, Indonesia Fauziyah Aulia Rishanti

\section{REFERENCES}

Agus Eko Sujianto, Aplikasi Statistik Dengan SPSS 16.0, (Jakarta: PT. Prestasi Pustakarya, 2009), hal. 94

Anthony, Robert N \& Govindarajan, Vijay. 2005. Management Control System. Salemba Empat. Jakarta.

Burhan Bungin. (2007). Metode Penelitian Kuantitatif: Komunikasi, Ekonomi, dan Kebijakan Publik serta Ilmuilmu Sosial Lainnya. Jakarta: Kencana.

Deddy Mulyadi. (2012). Pengantar Ilmu Komunikasi. Jakarta: Penerbit Rosda

Dwi Suhartanto, (2004). Riset Pemasaran. Bandung: Alfabeta Pres. hal.147

Hasibuan Sayuti. (2000). Pengembangan Sumber Daya Manusia. Jakarta: Gramedia.

Herman, N. (2016, September 27). Penguasaan Bahasa Inggris Penting dan Strategis. Retrieved from https://tniad.mil.id/kursus-bahasa-inggris-tingkatkan-kemampuan-personel/

Herry Gunawan (2010). Pengantar Transportasi dan Logistik. Jakarta: Rajawali Press.

Jodai, H. (2012). Evaluation of Worldview Textbook: Textbooks Taught at a Military University. International J. Soc.Sci. \&Education, Vol. 3, Issue 1

Koentjaraningrat, (1983). Metode-Metode Penelitian Masyarakat. Jakarta: Gramedia.

Muhammad, Metodologi Penelitian Ekonomi Islam Pendekatan Kuantitatif, (Jakarta: Rajawali Pers, 2013), hal.180

Nawawi Hadari. (2003). Manajemen Sumber Daya Manusia. Yogyakarta: Gajah Mada Press.

Nursalam. (2011). Konsep dan penerapan metodologi penelitian ilmu keperawatan. Jakarta : Salemba Medika.

Puguh Suharso, (2010). Metode Penelitian Kuantitatif Untuk Bisnis: Pendekatan Filosofis dan Praktis. Jakarta Barat: PT Indeks.

Pujawan, I Nyoman., dkk. (2010). Supply Chain Management Edisi Kedua. Surabaya: Guna Widya.

Siagian, Burhanuddin (2013). "Peningkatan Peran Lembaga Pendidikan TNI AD Guna Menjaga Legitimasi di Dunia Internasional”. Kajian Triwulan I Seskoad Bandung. (https://seskoad.mil.id/admin/file/kajian/35\%20Kajian\%20Peran\%20Lemdik.pdf)

Sugiyono, (2013). Metode Penelitian Kuantitatif, Kualitatif, dan Kombinasi (Mixed methods). Bandung: Alfabeta. Sugiyono, (2014). Metode Penelitian Mnajemen. Bandung: Alfabeta.

Sugiyono, (2015). Metode Penelitian Kuantitatif, Kualitatif, dan R\&D. Bandung: Alfabeta.

Sutarman. (2017). Dasar-Dasar Manajemen Logistik. Bandung: Refika Aditama.

Wiratna Sujarweni, (2015). Metodologi Penelitian - Bisnis \& Ekonomi, Yogyakarta: Pustaka Baru Press. 